\title{
Neck pain and factors associated in University Students: a cross sectional study
}

\section{Dor cervical e fatores associados em estudantes universitários: um estudo transversal}

\author{
Alberto De Vitta ${ }^{1}$ \\ José Paulo Candido ${ }^{2}$ \\ Thiago Bento ${ }^{2}$ \\ Guilherme Porfirio Cornelio ${ }^{2}$ \\ Priscila de Oliveira Perrucini ${ }^{1}$ \\ Julio Alberto Agante Fernandes ${ }^{3}$ \\ Wagner Ramos ${ }^{3}$
}

\section{ABSTRACT}

INTRODUCTION: Neck pain is a musculoskeletal condition with high prevalence that may affect the physical, social and psychological aspects of the individual, contributing to the increase in costs in society and business. OBJECTIVES: To determine the prevalence of neck pain and to analyze the association with the individual, sociodemographic variables and electronic devices. METHODS: A cross-sectional observational study was carried out with a sample of 1143 university students, who answered the questionnaire on sociodemographicaspects, use of electronic devices and the Nordic questionnaire. Descriptive, bivariate and Poisson regression analyzes were performed. RESULTS: The prevalence of neck pain was $66.7 \%$ (CI 63.8 to 69.3), and 57.6\% (CI 52.9 to 62.1) were men and $72.3 \%$ (CI 68.8 to 79.4) women. In the adjusted analysis, female ( $P R=1.92,1.49-2.47)$, time of use of TV above 3 hours per day (PR= $1,35 ; 1,05-1,79)$, time of use of computer above 3 hours per day ( $P R=1,41 ; 1,08-1,85)$, time of use of game above 3 hours per day $(P R=1,42 ; 1,02-1,97)$, using the tablet at a distance from the eye on the screen above $20 \mathrm{~cm}(P R=$ $1.08,1.01$ - 1.17), posture lying down in the use of the cell phone (PR = 1.67, 1.04 - 1.72), posture semi-lying down in the use of the cell phone $(\mathrm{PR}=1.28,1.02$ - 1.65), sitting posture in the use of the tablet $(\mathrm{PR}=1.54,1.03-2.38)$, lying down posture in the use of the tablet (PR = 1.83; , $05-3,18)$ and to use the tablet during two or more hours a day (PR $=2.28,1.15-4.49$ ) remained associated with neck pain. CONCLUSION: There is a high prevalence of neck pain in university students and striking association with the female sex and with the use of electronic devices.

\section{KEYWORDS}

Neck pain; Electronic devices; University students; Prevalence.

\footnotetext{
${ }^{1}$ Universidade Anhanguera-Uniderp, Campo Grande, MS.

${ }^{2}$ Universidade do Sagrado Coração

${ }^{3}$ Centro Universitário das Faculdades Integradas de Ourinhos
} 


\section{RESUMO}

INTRODUÇÃO: A dor cervical é uma condição musculoesquelética com alta prevalência que pode afetar os aspectos físicos, sociais e psicológicos dos indivíduos, contribuindo para o aumento de custos na sociedade e nos negócios. OBJETIVOS: Determinara prevalência de dor cervical e analisara associação com variáveis sociodemográficas e dispositivos eletrônicos. MÉTODOS: Foi realizado um estudo observacional transversal com uma amostra de 1143 universitários, que responderam ao questionário sobre aspectos sociodemográficos, uso de dispositivos eletrônicos e o questionário nórdico. Foram realizadas análises descritivas, bivariadas e de regressão de Poisson. RESULTADOS: A prevalência de dor cervical foi de 66,7\% (IC 63,8 a 69,3), sendo que, 57,6\% (IC 52,9 a 62,1) em homens e 72,3\% (IC 68,8 a 79,4) em mulheres. Na análise ajustada, o sexo feminino ( $R P=1,92,1,49-2,47)$, tempo de uso da TV acima de 3 horas por dia $(R P=1,35 ; 1,05-1,79)$, tempo de uso do computador acima de 3 horas por dia $(R P=1,41 ; 1,08$ - 1,85), tempo de uso de videogame acima de 3 horas por dia ( $R P=1,42 ; 1,02$ - 1,97), uso do tablet à distância do olho na tela acima de $20 \mathrm{~cm}(\mathrm{RP}=1,08,1,01-1,17)$, postura deitada no uso do celular $(\mathrm{RP}=1,67,1,04-1,72)$, postura semi-deitada no uso do celular $(R P=1,28 ; 1,02-1,65)$, postura sentada no uso do tablet $(R P=1,54 ; 1,03-2,38)$, postura deitada no uso do tablet $(\mathrm{RP}=1,83 ; 05-3,18)$ e usar o tablet por duas ou mais horas por dia $(\mathrm{RP}=2,28,1,15$ - 4,49) permaneceu associado à dor cervical. CONCLUSÃO: Existe alta prevalência de dor cervical em estudantes universitários e associação marcante com o sexo feminino e com o uso de dispositivos eletrônicos.

\section{PALAVRAS-CHAVE}

Dor cervical; Dispositivos eletrônicos; Estudantes universitários; Prevalência. 


\section{INTRODUCTION}

Neck musculoskeletal symptoms are common health complaints. A epidemiologic study demonstrated that the annual incidence rate of neck pain is $10.4-21.3 \%$ with a higher rate for office and computer workers (HOY et al., 2010). In the college student population, one-year prospective cohort study demonstrated a high incidence rate at $46 \%$ and of whom $33 \%$ reported persistent neck pain. Such high prevalence of neck and shoulder symptoms, especially among the younger populations, presents a substantial burden to the society(HOY et al., 2010; KANCHANOMANI et al., 2011).

In developed and developing countries, the most common of neck pain has been reported in university students. In Finland the prevalence of cervical pain was 29\% (OKSANEN et al., 2014), 34.6\% in Australia (SMITH AND LEGGAT, 2004), 54\% in the USA(JENKINS et al., 2004 ) , 49.7\% in Brazil (MATTOS et al, 2009), 46\% in Thailand (KANCHANOMAI et al., 2011), Saudi Arabia (GHARIB AND HAMID, 2013) of 54\%, in Korea (KIM AND KIM, 2013) of55.8\%, and in China (WOO et al., 2016) of $49.9 \%$.

This condition has a complex etiology, including a number of factors: ergonomic (strenuous physical activity, use of force and vibration, inappropriate posture, repetitive movement), individual (age, sex, body mass index, genome, musculoskeletal pain history) psychosocial (job satisfaction, stress level, anxiety and depression) and the use of electronic devices - TV, computer,tablet,gamesandcellphones(KANCHANOMAI et al., 2011; RAZVI et al., 2018; KALIRATHINAM et al., 2017; LEE et al., 2018).

International literature has shown that in Malaysian (RAZVI et al., 2018), Indian (KALIRATHINAM et al., 2017), Canadian (BEROLO et al., 2011) and Iranian (BAYATIANI et al., 2016) university studentsneck pain was related to the duration and frequency of cell phone uses, but with the Koreans there was no association. Regarding tablet use, it was observed an association between Canadian(BEROLO et al., 2011) students and American (LEE et al., 2018; BLAIR et al., 2015), whereas, with Chinese (CHIANG AND LIU, 2016) university students this fact didn't process. In Brazil, there are few epidemiological studies on neck pain in university students.
This study will contribute as a reference for other epidemiological investigations and may contribute to the knowledge of the national estimate of prevalence and its risk factors for systematic reviews and metaanalysis, since the availability of data sources from Brazilian surveys related to the outcome are scarce. There is also a lack of studies on the association of cervical pain with the use of electronic devices (tablet and cell phone) in Brazilian university students.

Studies on the prevalence and risk factors of neck pain in the population are important because they generate social and economic consequences, both for the State and individuals. The economic burden due to neck disorders is high and includes treatment costs, lack of work and disability payments. There is also inability related to neck pain and related recurrences which can significantly affect workforce productivity and the economics of families and communities. The economic burden of neck pain loses only to low back pain in workers' compensation claims in the United States and Sweden, and cervical and shoulder problems account for $18 \%$ of all disability payments (CHILDS et al., 2018).

Considering these points, the objective of this study was to determine the prevalence of neck pain and to analyze the association with the individual, sociodemographic variables and use of electronic devices.

\section{MATERIALS AND METHODS}

Study cross-sectional design, approved by the Ethics in Research Committee ofUniversidadeSagradoCoração, Bauru-SP (number 1.972.579), with 1143 university students.

For the calculation of sample size, the following parameters were used: the population equal to 5,941 students, including the bachelor's and teaching degree, the prevalence of the outcome unknown (50\%), sampling error equal to 4 percentage points and a confidence interval of $95 \%$ (95\% CI). The sample size obtained was multiplied by 2 dues to the effect of the study delineation (deff), added of $20 \%$ of expected losses and $15 \%$ for association studies, totaling 1,143 students.

In the selection process, the proportion of students distributed according to courses and classes was considered. Thus, the sample selection was done by 
conglomerate in two stages, with all the raffles performed at random. At first, the sampling unit was the course, being all students are eligible to participate in the study, considering the density of students per course. In the second, all classes (smaller sample unit) of the courses were considered eligible for the study. A simple random sampling was used, and as a criterion of stratification, the density of classes per period of each course was considered.

The exclusion criteria were: (a) foreign students in institutional exchanges, (b) in gestation period, and (c) with physical limitations (such as morbid obesity, amputation of a limb, spinal cord trauma).

\section{Data collection procedures}

TheUniversitywasrequestedaletterofauthorization for the accomplishment of the research in the university. The procedures adopted for data collection included: (a) prior contact with professors of each course via e-mail or telephone contact, with the sending of the terms of consentandscheduleforsubsequentapplication of the questionnaire to the class and (b) training of procedures among the evaluators.

The data collection occurred during the months of March and April of 2016, being performed by the researcher and two more students of the undergraduate course in physiotherapy, trained based on the protocol of standardization of data collection procedures (theoretical and practical), previously established in order to minimize possible intra and inter-raters errors.

For the data collection the following procedure was performed: first the researcher explained the research objectives, and students were informed about the voluntary nature of participation, the possibility of abandoning the research at any time and the right to confidentiality of individual data. In the sequence, they were requested to sign the Informed Consent Form (ICF) and the questionnaires were distributed with receiving instructions and recommendations for filling, not being established time limit for the same. During the process, the eventual doubts were promptly answered by the interviewer that accompanied the data collection. During the filling out of the questionnaire, the students did not communicate among themselves, in order to minimize possible undesirable interference in their answers.

The coding was performed by the interviewers themselves soon after the interviews and reviewed by supervisors of field work. The supervisors also performed the quality control that consisted of the application of questionnaires with reduced number of questions to $10 \%$ of the respondents.

\section{Instruments}

Neck pain, reported in the 12 months prior to the interview, represented the variable response of interest in this study. It was observed using the Nordic questionnaire, validated and adapted to Brazilian culture (BARROS AND ALEXANDRE, 2003).Neck pain was defined as pain, suffering or discomfort in the area between the occipital bone and the third thoracic vertebra, and between the medial border of the scapula (FEJER AND HARTVIGSEN, 2008). In the interview, individuals were asked the following question: "Did you have any pain or discomfort in the neck in the past year?" In addition to the verbal questionnaire, an image of the spinal regions in different colors was also presented, so the interviewees could better specify the neck region where the pain was(BARROS AND ALEXANDRE, 2003).

The form for the characterization of the subjects was made up of items related to the socio-demographic aspects: sex (women or men), age, marital status (married or consensual, single, divorced and widowed) skin color (white, black, brown, asiatic and indigenous) and the income was determined in minimum wages (MW) - low: up to 3 times the MW; middle: from 4 to 9 MW; and high: 10 or more MW- (PALMA et al., 2014).

In relation to electronic devices (use of TV, computer, tablet or mobile phone) the following questions were asked: "In a normal week class do you watch TV?" (yes/ no); "How many times a week do you watch TV?" (once or twice, three or four times, five times, more than five times); "How many hours a day do you watch TV?" (less than one hour, two hours, three hours, four hours, five hours, more than five hours a day); "Do you use your computer?" (yes/no); "What type of computer do you use?" (Desktop/Laptop); "What is the height of your PC screen?" (eyes above the midpoint of the screen, eyes approximately in the middle point of the screen, eyes below the mid-point of the screen); "How many times a week do you use computer?" (once or twice, three or four times, five times, more than five times); "How many hours a day do you use computer?" (less than one hour, two hours, three hours, four hours, five hours, more than five hours a day); What is the eye-to-screen distance while using your computer? $(<20 \mathrm{~cm}, 20 \mathrm{~cm}$ to $25 \mathrm{~cm}$ 
$25 \mathrm{~cm}$ to $30 \mathrm{~cm}$ and $>30 \mathrm{~cm}$ ); "Do you use your cell phone?" (yes/no); "What posture do you use the mobile phone?" (Standing, sitting, lying or semi-lying); "Average daily time using cell phone?" $(<1 \mathrm{~h}, 2 \mathrm{~h}$ and $3 \mathrm{~h}, 3 \mathrm{~h}$ and $4 \mathrm{~h}$ and $4 \mathrm{~h})$; "What is the eye-to-screen distance during the use of the cell phone?" $(<10 \mathrm{~cm}, 10 \mathrm{~cm}$ to $15 \mathrm{~cm}, 15$ cm to $20 \mathrm{~cm}$ and $>20 \mathrm{~cm}$ ); "Do You Use tablet?" (yes/no); "What posture do you use the tablet?" (Standing, sitting, lying or semi-lying); "Average daily time using tablet?" ( $<1 \mathrm{~h}, 2 \mathrm{~h}$ to $3 \mathrm{~h}, 3 \mathrm{~h}$ to $4 \mathrm{~h}$ and $>4 \mathrm{~h}$ ); "What is the eye-toscreen distance while using the tablet? $(<10 \mathrm{~cm}, 10 \mathrm{~cm}$ to $15 \mathrm{~cm}, 15 \mathrm{~cm}$ to $20 \mathrm{~cm}$ and $>20 \mathrm{~cm}$ ).

\section{Data analysis}

Data analysis was performed in the program Statistical Package for the Social Sciences (IBM SPSS Statistics 18.0 - SPSS. Inc., Chicago, Illinois 60606, USA). In the descriptive analysis, the prevalence of all the variables included in the study was calculated, with the respective confidence intervals. The demographic, socioeconomic and electronic devices were considered independent variables. Independent variables with a significance level of $p<0.20$ in bivariate analysis were included in a Poisson regression model with robust variance, and the assumptions required for Poisson regression to yield a valid result were respected. The effect measure is presented as prevalence ratio (PR) with 95\% confidence interval (CI). The threshold $\alpha=$ 0.05 was used to indicate statistical significance.

\section{RESULTS}

1,143 students were studied, already deducted from the final percentage of $2.05 \%$ of refusals. Of this total, $66.7 \%$ (CI 63.8 to 69.3) reported neck pain for at least some time in the 12 months preceding the interview, $57.6 \%$ (CI 52.9 to 62.1 ) for men and $72.3 \%$ (CI 68.8 to 79.4) for women, with a statistically significant difference.

Regarding the sociodemographic characteristics of the sample, $82.9 \%$ of the men and $90.0 \%$ of the women are in the age group of 18 to 25 years, $77.2 \%$ of the men and $83.3 \%$ of the women are of the white race white, $92.0 \%$ of males and $91.8 \%$ of females are single, and $78.1 \%$ of males and $79.6 \%$ of females are middle income.

The variables related to the use of electronic devices in high school adolescents are presented in Table 1.

Table 1. Distribution of absolute and relative frequencies regarding the use of electronic devices in university students.

\begin{tabular}{|c|c|c|}
\hline \multirow[b]{2}{*}{ Factors } & \multicolumn{2}{|l|}{ Sex } \\
\hline & Male $(n=439)$ & Female $(\mathrm{n}=704)$ \\
\hline \multicolumn{3}{|l|}{ Watch TV } \\
\hline No & $92(21.0 \%)$ & $92(13.1 \%)$ \\
\hline Yes & $347(79.0 \%)$ & $612(86.9 \%)$ \\
\hline \multicolumn{3}{|c|}{ How many times TV/week } \\
\hline Up to 2 times & $156(35.5 \%)$ & $239(33.9 \%)$ \\
\hline 3 times or more & $191(43.3 \%)$ & $373(53.0 \%)$ \\
\hline \multicolumn{3}{|c|}{ How many hours TV/day } \\
\hline Up to $2 \mathrm{~h}$ & $253(35.5 \%)$ & $429(34.0 \%)$ \\
\hline Above $3 \mathrm{~h}$ & $94(10.7 \%)$ & $183(14.7 \%)$ \\
\hline \multicolumn{3}{|l|}{ Use the computer } \\
\hline No & $2(0.5 \%)$ & $5(0.7 \%)$ \\
\hline Yes & $437(99.5 \%)$ & $699(99.3 \%)$ \\
\hline \multicolumn{3}{|l|}{ Type of computer } \\
\hline Desktop & $176(40.1 \%)$ & $160(22.7 \%)$ \\
\hline Laptop & $247(56.3 \%)$ & $513(72.9 \%)$ \\
\hline Desktop and Laptop & $14(3.2 \%)$ & $26(3.7 \%)$ \\
\hline \multicolumn{3}{|c|}{ Height of the computer screen } \\
\hline Above the midpoint & $133(30.3 \%)$ & $184(26.1 \%)$ \\
\hline Above the midpoint & $229(52.2 \%)$ & $373(53.0 \%)$ \\
\hline Above the midpoint & $75(17.1 \%)$ & $142(20.2 \%)$ \\
\hline
\end{tabular}




\begin{tabular}{|c|c|c|}
\hline Less than $30 \mathrm{~cm}$ & $191(43.5 \%)$ & $445(63.2 \%)$ \\
\hline $30 \mathrm{~cm}$ or more & $246(56.0 \%)$ & $254(36.1 \%)$ \\
\hline \multicolumn{3}{|c|}{ How many times computer/week } \\
\hline Up to 2 times & $24(5.5 \%)$ & $61(8.7 \%)$ \\
\hline 3 times or more & $413(94.1 \%)$ & $638(90.6 \%)$ \\
\hline \multicolumn{3}{|c|}{ How many hours computer/day } \\
\hline Up to $2 \mathrm{~h}$ & $110(25.1 \%)$ & $212(30.1 \%)$ \\
\hline Above $3 \mathrm{~h}$ & $327(74.5 \%)$ & $487(69.2 \%)$ \\
\hline \multicolumn{3}{|l|}{ Use videogame } \\
\hline No & $280(63.8 \%)$ & $617(87.6 \%)$ \\
\hline Yes & $159(36.2 \%)$ & $87(12.4 \%)$ \\
\hline \multicolumn{3}{|c|}{ How many times videogame/week } \\
\hline Up to 2 times & $107(24.4 \%)$ & $74(10.5 \%)$ \\
\hline 3 times or more & $52(11.8 \%)$ & $13(1.8 \%)$ \\
\hline \multicolumn{3}{|c|}{ How many hours videogame/day } \\
\hline Up to $2 \mathrm{~h}$ & $118(26.9 \%)$ & $70(9.9 \%)$ \\
\hline Above $3 \mathrm{~h}$ & $41(9.3 \%)$ & $17(2.4 \%)$ \\
\hline \multicolumn{3}{|l|}{ Use cell phone } \\
\hline No & $8(1.8 \%)$ & $3(0.4 \%)$ \\
\hline Yes & $431(98.2 \%)$ & $701(99.6 \%)$ \\
\hline \multicolumn{3}{|c|}{ What posture use the cell phone } \\
\hline Standing & $261(59.5 \%)$ & $434(61.6 \%)$ \\
\hline Sitting & $335(76.3 \%)$ & $579(82.2 \%)$ \\
\hline Lying down & $226(51.5 \%)$ & $470(66.8 \%)$ \\
\hline Semi-lying & $166(37.8 \%)$ & $377(53.6 \%)$ \\
\hline \multicolumn{3}{|l|}{ Daily use time } \\
\hline Up to $2 \mathrm{~h}$ & $166(23.6 \%)$ & $166(37.8 \%)$ \\
\hline $3 \mathrm{~h}$ or more & $265(60.4 \%)$ & $535(76.0 \%)$ \\
\hline \multicolumn{3}{|c|}{ Distance from the eye to the cell phone } \\
\hline Less than $20 \mathrm{~cm}$ & $261(59.5 \%)$ & $584(83.0 \%)$ \\
\hline $20 \mathrm{~cm}$ or more & $170(38.7 \%)$ & $117(16.6 \%)$ \\
\hline \multicolumn{3}{|l|}{ Use tablet } \\
\hline No & $385(87.7 \%)$ & $598(84.9 \%)$ \\
\hline Yes & $54(12.3 \%)$ & $106(15.1 \%)$ \\
\hline \multicolumn{3}{|c|}{ What posture use the tablet } \\
\hline Standing & $20(4.6 \%)$ & $14(2.0 \%)$ \\
\hline Sitting & $41(9.3 \%)$ & $78(11.1 \%)$ \\
\hline Lying down & $24(5.5 \%)$ & $53(7.5 \%)$ \\
\hline Semi-lying & $19(4.3 \%)$ & $42(6.0 \%)$ \\
\hline \multicolumn{3}{|l|}{ Daily use time } \\
\hline Up to $2 \mathrm{~h}$ & $43(5.9 \%)$ & $90(7.7 \%)$ \\
\hline $3 \mathrm{~h}$ or more & $11(2.5 \%)$ & $16(2.3 \%)$ \\
\hline \multicolumn{3}{|c|}{ Distance from the eye to the tablet } \\
\hline Less than $20 \mathrm{~cm}$ & $22(5.0 \%)$ & $96(13.6 \%)$ \\
\hline $20 \mathrm{~cm}$ or more & $32(7.3 \%)$ & $10(1.4 \%)$ \\
\hline
\end{tabular}


In table 2 there is a statistically significant association between neck pain with the female.

Table 2. Prevalence of neck pain by sociodemographic characteristics.

\begin{tabular}{|c|c|c|c|c|}
\hline \multirow{3}{*}{ Factors } & \multirow{3}{*}{ Total } & \multicolumn{3}{|c|}{ Neck pain } \\
\hline & & \multicolumn{3}{|c|}{ Prevalence } \\
\hline & & $\mathrm{N}$ & $\%$ & RP (IC 95\%) \\
\hline \multicolumn{5}{|l|}{ Sex } \\
\hline Men & 439 & 253 & 57,6 & 1,00 \\
\hline $\begin{array}{l}\text { women } \\
\text { Age group }\end{array}$ & 704 & 509 & 72,3 & $1,25(1,14-1,38)$ \\
\hline 18to 20 & 501 & 348 & 69,5 & 1,00 \\
\hline 21 to 25 & 497 & 320 & 64,4 & $0,93(0,85-1,01)$ \\
\hline 26 to 30 & 85 & 59 & 69,4 & $1,00(0,86-1,16)$ \\
\hline $\begin{array}{l}31 \text { ormore } \\
\text { Race }\end{array}$ & 60 & 35 & 58,3 & $0,84(0,67-1,05)$ \\
\hline White & 925 & 630 & 68,1 & $\begin{array}{l}1,00 \\
0,88\end{array}(0,77-1,01)$ \\
\hline Parda/mulatto & 150 & 90 & 60,0 & $0,98(0,55-1,73)$ \\
\hline Indigenous & 6 & 4 & 66,7 & \\
\hline Black & 36 & 22 & 61,1 & $0,90(0,69-1,17)$ \\
\hline $\begin{array}{l}\text { Asiatic } \\
\text { Marital Status }\end{array}$ & 26 & 16 & 61,5 & $0,90(0,66-1,23)$ \\
\hline Marriage & 82 & 58 & 70,7 & 1,00 \\
\hline Single & 1050 & 698 & 66,5 & $0,94(0,81-1,09)$ \\
\hline $\begin{array}{l}\text { Divorced/widower } \\
\text { Income }\end{array}$ & 11 & 6 & 60,0 & $0,85(0,50-1,43)$ \\
\hline Upper & 83 & 58 & 69,9 & 1,00 \\
\hline Middle & 151 & 113 & 74,8 & $1,07(0,90-1,27)$ \\
\hline Low & 909 & 591 & 65,4 & $0,94(0,80-1,09)$ \\
\hline
\end{tabular}

In table 3 there was an association with the time of use of TV above 3 hours per day, time of use of game above 3 hours per day, use of the cell in the lying postures, , use of the cell in the semi-lying down posture,use of the tablet, use of the tablet above 2 hours per day.

Table 3. Prevalence of neck pain by electronic devices.

\begin{tabular}{|c|c|c|c|c|}
\hline \multirow{3}{*}{ Factors } & \multirow{3}{*}{ Total } & \multicolumn{3}{|c|}{ Neckpain } \\
\hline & & \multicolumn{2}{|c|}{ Prevâlence } & \multirow{2}{*}{ RP (IC 95\%) } \\
\hline & & $\mathrm{N}$ & $\%$ & \\
\hline \multicolumn{5}{|l|}{ Watch TV } \\
\hline No & 184 & 122 & 66,3 & 1,00 \\
\hline Yes & 959 & 640 & 66,7 & $1,01(0,9-1,13)$ \\
\hline \multicolumn{5}{|c|}{ How many times TV/week } \\
\hline Upto 2 times & 325 & 203 & 78,2 & 1,00 \\
\hline 3 times or more & 634 & 437 & 50,8 & $1,54(1,39-1,71)$ \\
\hline \multicolumn{5}{|c|}{ How many hours TV/day } \\
\hline Upto $2 \mathrm{~h}$ & 395 & 245 & 62,0 & 1,00 \\
\hline Above 3h & 564 & 395 & 70,0 & $0,89(0,81-0,97)$ \\
\hline \multicolumn{5}{|l|}{ Use thecomputer } \\
\hline No & 7 & 3 & 42,9 & 1,00 \\
\hline Yes & 1136 & 759 & 66,8 & $1,55(0,66-3,64)$ \\
\hline \multicolumn{5}{|l|}{ Typeofcomputer } \\
\hline Desktop & 760 & 515 & 67,8 & 1,00 \\
\hline
\end{tabular}




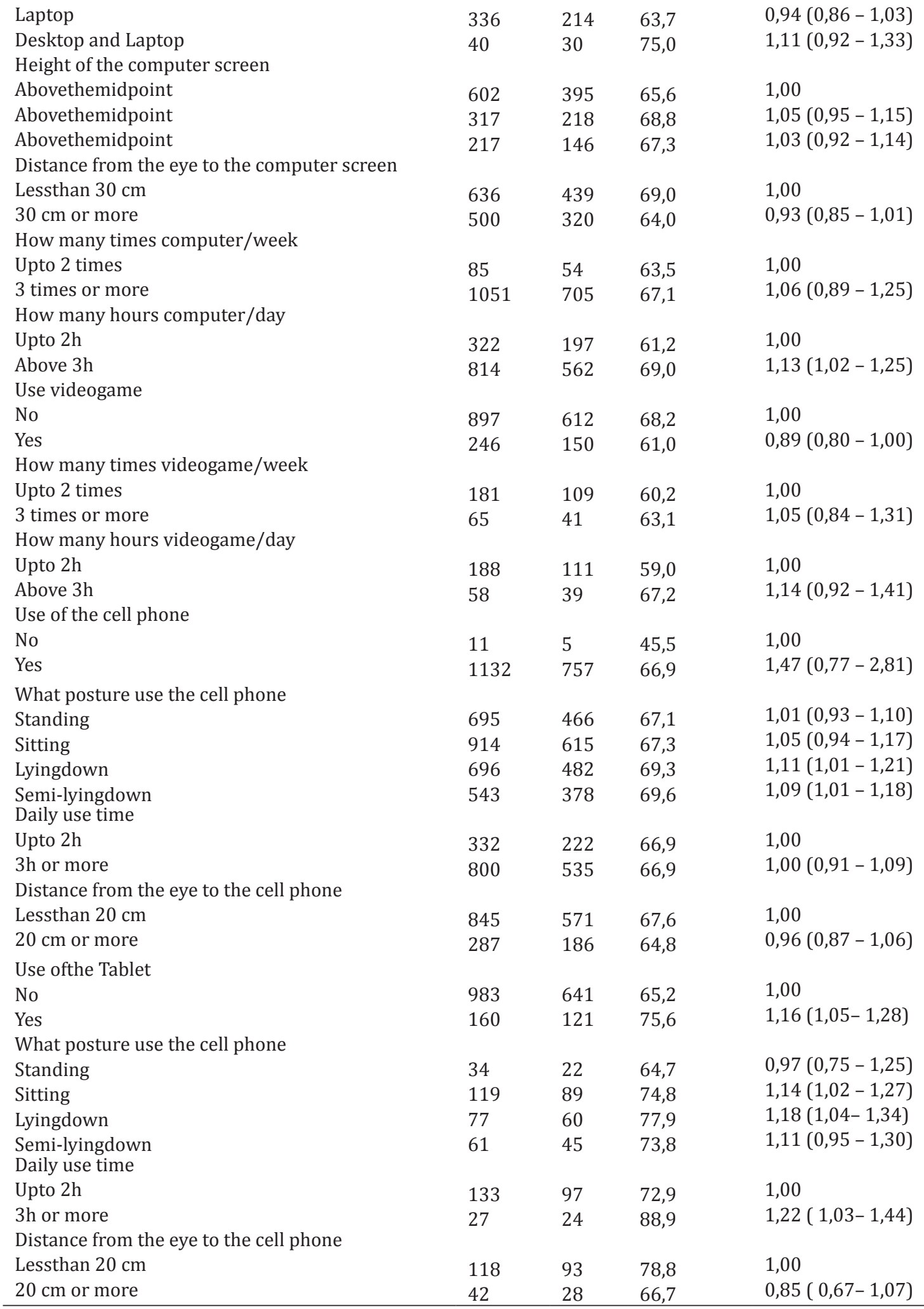


In Poisson regression the associations with neck pain remained for thefemale (PR $=1.92,1.49-2.47$ ), time of use of TV above 3 hours per day (PR=1,35; 1,05 - 1,79), time of use of computer above 3 hours per day $(P R=1,41 ; 1,08$ - 1,85), time of use of game above 3 hours per day ( $P R=1,42 ; 1,02-1,97$ ), using the tablet at a distance from the eye on the screen above $20 \mathrm{~cm}(\mathrm{PR}=1.08,1.01-1.17)$, posture lying down in the use of the cell phone $(\mathrm{PR}=1.67,1.04$ - 1.72), Posture semi-lying down in the use of the cell phone ( $P R=1.28,1.02-1.65)$, sitting posture in the use of the tablet $(\mathrm{PR}=1.54,1.03-2.38)$, lying down posture in the use of the tablet $(\mathrm{PR}=1.83 ;, 05-3,18)$ and to use the tablet during two or more hours a day (PR = 2.28, 1.15 - 4.49), remained associated with neck pain (Table 5).

Table 5. Poisson Regression analysis, final model, for associations of variables studied with neck pain.

\begin{tabular}{|c|c|c|c|}
\hline \multicolumn{4}{|c|}{ Neck pain } \\
\hline Factors & & $\mathrm{p}$ value & Adjusted $\mathrm{PR}^{*} / 95 \% \mathrm{CI}^{*}$ \\
\hline \multicolumn{4}{|l|}{ Sex } \\
\hline & Men & - & 1.00 \\
\hline & Female & 0,0001 & $1.92(1,49-2.47)$ \\
\hline \multirow[t]{3}{*}{ How many hours TV/day } & & & 1.00 \\
\hline & Upto $2 \mathrm{~h}$ & & $1.35(1.05-1.79)$ \\
\hline & Above $3 \mathrm{~h}$ & & \\
\hline \multirow[t]{3}{*}{ How many hours computer/day } & & & 1.00 \\
\hline & Upto $2 \mathrm{~h}$ & & $1,41(1,08-1,85)$ \\
\hline & Above $3 h$ & & \\
\hline \multirow[t]{3}{*}{ How many hours videogame/day } & & & 1.00 \\
\hline & Upto $2 \mathrm{~h}$ & & $1,42(1,02-1,97)$ \\
\hline & Above $3 h$ & & \\
\hline \multicolumn{4}{|c|}{ Distance from the eye to screen of tablet } \\
\hline & to $20 \mathrm{~cm}$ & - & 1,00 \\
\hline & $20 \mathrm{~cm}$ or more & 0,01 & $1,08(1,01-1,17)$ \\
\hline \multicolumn{4}{|c|}{ Posture lying down in the use of the cell phone } \\
\hline & No & - & 1,00 \\
\hline & Yes & 0,0001 & $1,67(1,04-1,72)$ \\
\hline \multicolumn{4}{|c|}{ Posture semi-lying down in the use of the cell phone } \\
\hline & No & - & 1,00 \\
\hline & Yes & 0,04 & $1,28(1,02-1,65)$ \\
\hline \multicolumn{4}{|l|}{ Sitting posture in the use of the tablet } \\
\hline & No & & 1,00 \\
\hline & Yes & 0,04 & $1,54(1,03-2,38)$ \\
\hline \multicolumn{4}{|c|}{ Posture lying down in the use of tablet } \\
\hline & No & - & 1,00 \\
\hline & Yes & 0,03 & $1,83(1,05-3,18)$ \\
\hline \multicolumn{4}{|l|}{ How many hours tablet/day } \\
\hline & Upto $2 \mathrm{~h}$ & - & 1,00 \\
\hline & Above $3 \mathrm{~h}$ & 0,01 & $2,28(1,15-4,49)$ \\
\hline
\end{tabular}




\section{DISCUSSION}

In the present study, the prevalence of neck pain was $66.7 \%$ higher than in $29.0 \%$ in Finland (OKSANEN et al., 2014), 52.8\% in Australia (SMITH AND LEGGAT, 2004), $33.0 \%$ in Thailand (KANCHANOMAI ET AL., 2011), in Brazil (MATTOS et al., 2009), 54.0\% in Saudi Arabia (GHARIB AND HAMID, 2013), 55.8\% in Korea (WOO et al., 2016) and 28.0\% in Ghana (ABLEDU AND OFFEI, 2015), similar to what was reported in studies from Jordan(ALMHDAWI et al., 2017), in Australia (SMITH et al., 2006)and in Italy (LORUSSO et al., 2009).

The womenwere 1.92 more likely to present cervical pain. In Thailand (KANCHANOMAI ET AL., 2011) it was 1,43, in Finland(OKSANEN et al., 2014), it was 2,30, in Australia (SMITH et al., 2006) it was 3,40 and in China (W00 et al., 2016) it was 1,61. Differences between men and women can be explained by some assumptions. The first is related to physical strength, which is lower in women than in men, making their energy expenditure greater when exposed to the demand for similar work, increasing the risk of musculoskeletal overload. The second refers to psychosocial factors, in which women report their complaints more frequently than men. Women have a more social and educational permission profile to talk about their symptoms and a more developed observation capacity (LEE et al., 2018; SILVA et al., 2016; YAO et al., 2012).

Using the devices electronics (TV, computer, game and tablet) for three hours or more were associated with neck pain similar to studies (DOCKRELL et al., 2015; HAYESet al., 2009; RAKHADANI et al., 2017; KIM et al., 2015), whereas in other investigations there were no associations (KANCHANOMAIet al., 2011; OBEMBE et al., 2013; CHIANG AND LIU, 2016).

This association may be due to prolonged sitting time, usually using incorrect postures, inadequate furniture, and poorly organized. Under these conditions, sitting posture generates various changes in musculoskeletal structures, increasing approximately $35 \%$ internal pressure in the intervertebral disc nucleus, stretching all structures (ligaments, small joints and nerves) of the spine, reducing return circulation. lower limbs and promotes the development of inflammatory processes in musculoskeletal structures with associated painful symptoms (XIE et al., 2017).
Another point, currently, is a the portability of tablets and cell phones provides continuous use in multiple workstations and non-traditional postures (eg on the couch or when using public transport) and associated with their design that do not allow the wrist and fingers to rest on the surface of the inadequate postures of the cervical spine, shoulders and increased muscular activity of the shoulder girdle (SHIN AND ZHU, 2011; KIM et al., 2014). As a result of this, it has been reported that users may present in cervical spine pain, headaches, fatigue, dizziness and tension (SHARAN et al., 2014).

Using the tablet at a distance from the eye on the screen above $20 \mathrm{~cm}$ and postures lying down, semi-lying and sitting wereassociated with neckpain, corroborating the study in the United States (LEE et al., 2018), whereas in another investigation this fact did not occur(WOO et al., 2016).

The combination of these postures and the distance of the equipment to the eyes causes the individuals to have an anterior head posture (FHP) that promotes an increase in flexion of the lower cervical vertebrae and upper thoracic regions, enlargement of the superior cervical vertebrae and extension of the occiput in C1. FHP is considered to coexist with hyperextension of the high cervical spine, flattening of the lower cervical spine, rounding of the upper back, and elevation and protraction of the shoulders.All these changes cause a constant isometric muscle contraction to support the head, a stretching of the suprahyoid muscles, narrowing of the intervertebral foramina in lordotic areas of the cervical region, and abnormal compression in the posterior zygapophysial joints and posterior portions of the intervertebral discs, resulting in cranial pain facial pain, headache, neck pain and shoulder pain, along with decreased cervical range of motion, muscle stiffness and sensitivity and degenerative changes(RAZVI et al., 2018; LEE et al., 2018; DOUGLAS AND GALLANGER, 2017).

This study had a number of methodological limitations: first, some confounding factors such as the types of tablets used, previous injuries and exposure to other technologies were not controllable. Second, no data were collected on how the outcome affected and / or limited their usual activities or caused changes in their daily routine and related to psychosocial factors. Third, the data were based on self-reported a response 
which increases the risk of recall bias. Finally, our sample was limited to the students of a university in Bauru and, therefore, caution should be exercised when generalizingtheresults of this study toother populations. The strength of this study is the consistency of the results with the literature, in the use of validated questionnaires for the outcome studied and the number of individuals interviewed.

Neck pain is a common condition that causes substantial disability. Considering that data available from national endpoint surveys are scarce in Brazil, this study will serve as a reference for other epidemiological investigations and will contribute to the national assessment of risk prevalence factors, systematic reviews and meta-analyzes. Further studies should be performed on the predictors and clinical outcome of cervical pain in different settings.

\section{CONCLUSION}

Finally, it was concluded that pain in the neck pain had a high prevalence and a strong association with female, time of use of TV above 3 hours per day, time of use of computer above 3 hours per day, time of use of game above 3 hours per day, using the tablet at a distance from the eye on the screen above $20 \mathrm{~cm}$, posture lying down in the use of the cell phone, posture semi-lying down in the use of the cell phone, sitting posture in the use of the tablet, lying down posture in the use of the tablet and to use the tablet during two or more hours a day. 


\section{REFERENCES}

ABLEDU, J. K.; OFFEI, E. B. Musculoskeletal disorders among first-year Ghanaian students in a nursing college. African health sciences, v. 15, n. 2, p. 444-49, 2015.

ALMHDAWI, K. A; MATHIOWETZ, V; AL-HOURANI, Z; KHADER, Y; KANAAN, S. F.; ALHASAN, M. Musculoskeletal pain symptoms among allied health professions' students: Prevalence rates and associated factors. J Back Musculoskelet Rehabil., v. 30, n. 6, p. 1291-1301,2017.

BARROS, E.N.C.; ALEXANDRE, N.M.C.Cross-Cultural adaptation of the Nordic Musculoskeletal Questionnaire. Int Nurs Rev., v. 50, n. 2, p. 101-108, 2003.

BEROLO, S.; WELLS, R. P.; AMICK, B.C. Musculoskeletal symptoms among mobile hand-held device users and their relationship to device use: a preliminary study in a Canadian university population. Applied Ergonomics, v42, n. 2, p. 37178,2011

BLAIR, B.; GAMA, M.; TOBERMAN, M. Prevalence and. Risk Factors for Neck and Shoulder Musculoskeletal Symptoms in Users of Touch-Screen Tablet Computers. (Doctorate Thesis of Physical Therapy). LasVegasUniversity of Nevada. 2015.

BAYATIANI, M.R.; SEIF, F.; BAYATI, A. The Correlation between Cell Phone Use and Sleep Quality in Medical Students. Iranian Journal of Medical Physics, v. 13, n. 1, p. 8-16, 2016.

CHIANG, H. Y. A; LIU, C. H. Exploration of the associations of touch-screen tablet computer usage and musculoskeletal discomfort. Work, v. 53, n. 4, p. 917-25, 2016.

CHILDS, J. D; CLELAND, J. A.; ELLIOTT, J. M.; TEYHEN, D. S; WAINNER, R. S; WHITMAN, J. M. et al. Neck pain: clinical practice guidelines linked to the International Classification of Functioning, Disability, and Health from the Orthopaedic. Journal of Orthopaedic\& Sports Physical Therapy, v. 38, n. 9, p. A1-A34, 2018.

DOUGLAS, E. C; GALLAGHER, K. M. The influence of a semireclined seated posture on head and neck kinematics and muscle activity while reading a tablet computer. Applied Ergonomics, v. 60, p. 342-47, 2017.

DOCKRELL, S.; BENNETT, K.; CULLETON-QUINN, E. Computer use and musculoskeletal symptoms among undergraduate university students. Computers \& Education, v. 85, p. 102-09, 2015.

FEJER, R.; HARTVIGSEN, J. Neck pain and disability due to neck pain: What is the relation? Eur Spine J, v. 17, n. 1, p. 80-88, 2008.

JENKINS, M.; MENÉNDEZ, C. C.; AMICK, B. C.; TULLA, R. J.; HUPERT, N.; ROBERTSON, M. M.; et al. Undergraduate college students' upper extremity symptoms and functional limitations related to computer use: A replication study. Work, v. 28, n. 3 , p. 231-38, 2007.

GHARIB, N. M.; HAMID, N. S. Prevalence of mechanical neck pain in Taif university female students: a survey study. Journal American Science, v. 9, n. 6, p. 347-54, 2013.

HAYES, M. J.; SMITH, D. R.; COCKRELL, D. Prevalence and correlates of musculoskeletal disorders among Australian dental hygiene students. International Journal of Dental Hygiene, v. 7, n. 3, p. 176-81, 2009.

HOY, D. G; PROTANI, M.; DE, R.; BUCHBINDER, R. The epidemiology of neck pain. Best Pract Res Clin Rheumatol, v 24, p. 783-792, 2010

KANCHANOMAI, S.; JANWANTANAKUL, P.; PENSRI, P.; JIAMJARASRANGSI, W. Risk factors for the onsetand persistence of neck pain in undergraduate students: 1-year prospective cohort study. BMC Public Health, v. 11, n. 1, p. 2-8, 2011.

KALIRATHINAM, D.; MANOHARLAL, M. A; CHONGLI, M.; LING, C. K; SHENG, T. W. Y.; JEROME, A.; et al. Association between the usage of Smartphone as the risk factor for the prevalence of upper extremity and neck symptoms among University students: A cross - sectional survey-based study. US Research J. Pharm and Tech, v. 10, n. 4, p. 1184, 2017.

KIM, J. H.; AULCK, L.; BARTHA, M. C.; HARPER, C.A.; JOHNSON P. W. Differences in typing forces, muscle activity, comfort, and typing performance among virtual, notebook, and desktop keyboards. Appl Ergon, v. 45, n. 6, p. 1406-13, 2014.

KIM, H. J.; KIM, J. S. The relationship between smartphone use and subjective musculoskeletal symptoms and university students. Journal of Physical Therapy Science, v. 27, n. 3, p. 575-79, 2015.

LEE, S.; HSU Y.; BLAIR, B.; TOBERMAN, M.; CHIEN, L. Gender and posture are significant risk factors to musculoskeletal symptom; during touchscreen tablet computer use. J. Phys. Ther. Sci, v. 30, p. 855-861, 2018.

LORUSSO, A.; BRUNO, S.; L'ABBATE, N. Musculoskeletal disorders among university student computer users. La Medicina del Lavoro, v. 100, n. 1, p. 29-34, 2009.

MATTOS, G. D. L. G.; LEITE, C.; MILMAN, L. D. M.; SOUZA, L. D. D. M.; LÜDTKE, I.; AMARAL, B.; et al. Cervicalgia em estudantes universitários do Sul do Brasil: prevalência e fatores associados. Medicina de Reabilitação, v. 28, n. 1, p. 15-20, 2009.

OBEMBE, A. O.; JOHNSON, O.; TANIMOWO, T. O.; ONIGBINDE, A. T.; EMECHETE, A. A. Musculoskeletal pain among undergraduate laptop users in a Nigerian University. Journal of Back and Musculoskeletal Rehabilitation, v. 26, n. 4, p. 389-95, 2013 
OKSANEN, A. M.; LAIMI, K.; LÖYTTYNIEMI, E.; KUNTTU, K. Trends of weekly musculoskeletal pain from 2000 to 2012: National study of Finnish university students. European Journal of Pain, v. 18, n. 9, p. 1316-322, 2014.

PALMA, R.; CONTI, M. H. S.; QUINTINO, N. M.; GATTI, M. A. N.; SIMEÃO, S. F. A. P.; VITTA, A. Functional capacity and its associated factors in the elderly with low back pain. Acta Ortop Bras, v. 22, n. 6, p. 295-9, 2014.

RAKHADANI, P. B.; GOON, D. T.; MANDEYA, A. Musculoskeletal Problems Associated with University Students Computer Users: A Cross-Sectional Study. Online Journal Health Allied Science, v. 16, n. 2, p. 1-7, 2017.

RAZVI, S. S. N. M.; SHEWALE, R. N.; KHATIB, S. K. Neck pain in young adults: impact of electronic device use and other associated factors. Indian Journal of Applied Research, v. 8, n. 10, p. 47-49, 2018.

SILVA, G. R. R.; PITANGUI, A. C. R.; XAVIER, M. K. A.; CORREIA JÚNIOR, M. A.V.; DE ARAÚJO, R. C. Prevalence of musculoskeletal pain in adolescents and association with computer and videogame use. Jornal de Pediatria, v. 92, n. 2, p. 188-96, 2016

SMITH, D. R.; LEGGAT, P. A. Musculoskeletal disorders among rural Australian nursing students. Australian Journal of Rural Health, v. 12, n. 6, p. 241-45, 2004.
SMITH, D. R.; LEGGAT, P. A.; CLARK, M. Upper body musculoskeletal disorders among Australian occupational therapy students. British Journal of Occupational Therapy, v. 69 , n. 8 , p. $365-72,2006$.

SHARAN, D.; MOHANDOSS, M.; RANGNATHANR, J. J. Musculoskeletal disorders of the upper extremities due to extensive usage of hand-held devices. Ann Occup Environ Med, v. 26, p. 2232, 2014.

SHIN, G.; ZHU, X. User discomfort, work posture and muscle activity while using a touchscreen in a desktop PC setting. Ergonomics, v. 54, n. 8, p. 733-44, 2011.

XIE, Y.; SZETO, G.; DAI, J. Prevalence and risk factors associated with musculoskeletal complaints among users of mobile handheld devices: a systematic review. Appl Ergon, v. 59, p. 132-42, 2017.

YAO, W.; LUO, C.; AI, F.; CHEN, Q. Risk factors for nonspecific low-back pain in Chinese adolescents: a case-control study. Pain Medicine, v. 13, n. 5, p. 658-64, 2013.

WOO, E. H; WHITE, P; LAI, C. W. Musculoskeletal impact of the use of various types of electronic devices on university students in Hong Kong: An evaluation by means of self-reported questionnaire. Manual Therapy, v. 26, p. 47-53, 2016. 